\title{
EFEK PEMBERIAN EKSTRAK BIJI JINTAN HITAM (NIGELLA SATIVA) TERHADAP KONSENTRASI GLUT-4 PADA TIKUS PUTIH (RATTUS NORVEGICUS) STRAIN WISTAR MODEL DIABETES MELITUS TIPE 2
}

\section{Effect of Black Seed (Nigella sativa) Extract for GLUT-4 Concentration on Wistar Strain of Albino Rat (Rattus norvegicus) as a Diabetes Mellitus Type 2 Model}

Efta Triastusi, M.Farm.Klin., Apt.*,Meutia Tamimi Auli ${ }^{1}$, Ema Pristi Yunita, M.Farm.Klin., Apt.*

*Program Studi Farmasi Fakultas Kedokteran Universitas Brawijaya Malang

\begin{abstract}
Diabetes Mellitus (DM) is a common problem in developing countries, including in Indonesia. Type 2 diabetes is characterized by insulin resistance that occursbecause of GLUT4 synthesis and translocation to cell surface reduction, it is caused by obstacle AMPK activity in muscle tissue because of excessive production of proinflammatory cytokines. Black seed contain thymoquinone which has antiinflammatory activity.The aim of this study was to determine the effects of black seed extract to the concentration of GLUT-4 in muscle tissue. True experimental design was used in this study, 25 male Wistar rats model type 2 DM were divided into 5 groups: negative control (10\% tween 80), positive control (metformin $75 \mathrm{mg} / \mathrm{kg}$ ), 3 groups received black seed extract in different dosages (24 mg/kg, $48 \mathrm{mg} / \mathrm{kg}$, and $96 \mathrm{mg} / \mathrm{kg}$ ). Induction of type 2 diabetes was conducted for 2 months using high energy diet containing $10 \%$ lard and 20\% sucrose combined with STZ injection $30 \mathrm{mg} / \mathrm{kg}$, followed by 1 month therapy. GLUT-4 concentration was measured by ELISA method, the result of this study indicate that there was nostatistically different concentration of GLUT-4 between each group (ANOVA, $p>0,05)$.

Keywords: Diabetes Mellitus type 2 (type 2 DM), high energy diet, STZ $30 \mathrm{mg} / \mathrm{kg}$, black seed extract, GLUT-4 concentration.
\end{abstract}




\section{ABSTRAK}

Diabetes Melitus (DM) merupakan masalah yang banyak terjadi di negara berkembang, salah satunya adalah di Indonesia.DM tipe 2 ditandai dengan keadaan resistensi insulin yang dapat terjadi karena penurunan sintesis dan translokasi GLUT-4 ke permukaan sel, hal tersebut disebabkan oleh hambatan aktivitas AMPK di jaringan otot karena produksi TNF- $\alpha$ yang berlebihan. Biji jintan hitam mengandung thymoquinone yang memiliki aktivitas sebagai antiinflamasi. Penelitian ini bertujuan untuk mengetahui efek ekstrak biji jintan hitam terhadap konsentrasi GLUT-4 di jaringan otot. Desain penelitian ini adalah true experimentaldengan sampel 25 ekor tikus putih jantan strain Wistar model DM tipe 2 yang dibagi ke dalam 5 kelompok yaitu kontrol negatif (10\% tween 80), kontrol positif (metformin $75 \mathrm{mg} / \mathrm{kgBB}$ ), 3 kelompok mendapat ekstrak biji jintan hitam dengan dosis yang berbeda $(24 \mathrm{mg} / \mathrm{kgBB}, 48$ $\mathrm{mg} / \mathrm{kgBB}$, dan $96 \mathrm{mg} / \mathrm{kgBB}$ ). Induksi $\mathrm{DM}$ tipe 2 dilakukan selama 2 bulan dengan menggunakan pakan tinggi kalori yang mengandung 10\% lemak babi dan 20\% sukrosa serta injeksi STZ $30 \mathrm{mg} / \mathrm{kgBB}$, lalu dilakukan terapi selama 1 bulan. Konsentrasi GLUT-4 diukur dengan menggunakan ELISA, hasilnya tidak terdapat perbedaan konsentrasi GLUT-4 yang signifikan antar kelompok (ANOVA, $p>0,05$ ).

Kata kunci: Diabetes Melitus tipe 2 (DM tipe 2), pakan tinggi kalori, STZ 30mg/kgBB, ekstrak biji jintan hitam, konsentrasi GLUT-4.

\section{PENDAHULUAN}

Diabetes Melitus (DM) merupakan masalah yang banyak terjadi di negara berkembang, salah satunya adalah di Indonesia. DM adalah penyakit yang ditandai dengan tingginya kadar glukosa dalam darah yang diakibatkan oleh ketidakmampuan tubuh untuk menghasilkan dan/atau menggunakan insulin ${ }^{4}$. Dua bentuk DM yang paling umum adalah DM tipe 1 dan DM tipe $2^{20}$. DM tipe 2 adalah kasus yang dominan setidaknya pada $90 \%$ dari kasus DM. DM tipe 2 ditandai dengan keadaan resistensi insulin dan kekurangan sekresi insulin. Resistensi insulin merupakan suatukondisi yang berhubungan dengan kegagalan organ target untuk merespon aktivitas hormon insulin. Resistensi insulin ditandai dengan penurunan sintesis dan translokasi GLUT-4 ke membran sel, GLUT-4 terdapat di beberapa jaringan, namun terutama terdapat di jaringan otot dan adiposa ${ }^{18}$.

Obesitas berhubungan dengan peningkatan jumlah dan/atau ukuran sel jaringan adiposa, sel ini memproduksi sitokin proinflamasi secara berlebihan seperti TNF- $\alpha^{23}$. TNF- $\alpha$ menghambat aktivitas AMPK (AMP-activated protein kinase) yang mengakibatkan resistensi insulin di jaringan otot $^{22}$. Penghambatan aktivitas AMPK mengakibatkan penurunkan sintesis dan translokasi GLUT4 di jaringan otot yang berkontribusi terhadap kondisi hiperglikemia ${ }^{5,14}$.

Biji jintan hitam (Nigella sativa) digunakan untuk mengobati DM karena memiliki efek menurunkan kadar glukosa darah, menstimulasi sel $\beta$ pankreas untuk mensekresi insulin, dan menghambat glukoneogenesis ${ }^{12}$. Essential oil merupakan salah satu komponen dari biji jintan hitam dengan kandungan utamanya adalah thymoquinoneyang diketahui dapat berperan sebagai antiinflamasi, dimana inflamasi merupakan salahsatu penyebab terjadinya resistensi insulin ${ }^{13}$. Penelitian ini bertujuan untuk mengetahui perbedaan konsentrasi GLUT-4 pada jaringan otot tikus model DM tipe 2 yang mendapatkan terapi ekstrak biji jintan hitam, metformin, dan tanpa terapi dan mengetahui dosis optimum ekstrak biji jintan hitam.

\section{METODE}

\section{Desain Penelitian}

Penelitian ini menggunakan desain true experimental, metode yang digunakan adalah posttest-only controlled design. Sampel berupa 25 ekor tikus strain Wistar jantan yang dibagi menjadi 5 kelompok perlakuan, yaitu kontrol postif (metformin 
$75 \mathrm{mg} / \mathrm{kgBB} /$ hari), kelompok ekstrak biji jintan hitam dengan berbagai dosis $(24,48$, dan $96 \mathrm{mg} / \mathrm{kgBB} /$ hari), kontrol negatif $(10 \%$ tween 80$)$.

\section{Ekstraksi}

Tahap ekstraksi biji jintan hitam merujuk dari jurnal Andaloussi tahun 2011 tentangefek ekstrak biji jintan hitam terhadap glukosa darah pada tikus DM tipe 2. Serbuk biji jintan hitam sebanyak 300 gram dimaserasi dengan Etanol $80 \%$ sebanyak $900 \mathrm{ml}$ dengan perbandingan simplisia dan pelarut $1: 3$ selama 24 jam. Dilakukan pengadukan selama 30 menit dengan kecepatan $1000 \mathrm{rpm}$. Remaserasi dilakukan sebanyak 2 kali. Hasil maserasi dipekatkan menggunakan rotatory evaporator pada suhu $<40^{\circ} \mathrm{C}$ hingga pelarut menguap, lalu dioven pada suhu $<$ $40^{\circ} \mathrm{C}$ hingga didapatkan ekstrak kental.

\section{Uji Fitokimia}

Prosedur uji fitokimia merujuk dari jurnal yang ditulis oleh Soerya Dewi Marliana tahun (2005) dan Depkes (1989) minyak atsiri diuji dengan sudan III, hasil positif ditunjukkan dengan perubahan warna ekstrak menjadi merah. Alkaloid diuji dengan menggunakan 2 reagen yaitu reagen Mayer dan Wagner, hasil positif dengan reagen Mayer ditunjukkan dengan adanya endapan kuning dan endapan merah pada ekstrak yang diberi reagen Wagner. Uji saponin dilakukan dengan pengocokan selama 1 menit, hasil positif ditunjukkan dengan terbentuknya busa di permukaan ekstrak dengan ketinggian 1-10 cm selama 10 menit.

\section{Induksi DM Tipe 2}

Induksi DM tipe 2 merujuk dari penelitian Wang tahun 2007, yaitu dengan pemberian pakan tinggi kalori yang mengandung 20\% sukrosa dan 10\% lemak babi selama 2 bulan, lalu dilanjutkan dengan injeksi STZ $30 \mathrm{mg} / \mathrm{kgBB}$ satu kali sebagai dosis tunggal.

Pengorbanan hewan coba dilakukan dengan dislokasi lehar pada tikus lalu jaringan otot diambil dari area paha.
Jaringan otot sebanyak $100 \mathrm{mg}$ ditambah $1 \mathrm{ml}$ larutan buffer lisis (tabel 1), lalu digerus. Diinkubasi pada suhu $4^{0} \mathrm{C}$ selama 30 menit, lalu disentrifugasi selama 10 menit dengan kecepatan $6000 \mathrm{rpm}$ pada suhu $4^{0} \mathrm{C}$. Supernatan dipisahkan untuk dianalisa.

Tabel 1. Resep Buffer Lisis

\begin{tabular}{clll}
\hline No. & Bahan & Jumlah & \multicolumn{1}{c}{ Fungsi } \\
\hline 1. & $\begin{array}{l}\text { Tris base } \\
\text { pH 8.0) }\end{array}$ & $0,121 \mathrm{~g}$ & $\begin{array}{l}\text { Mengatur } \mathrm{pH} \text { antara } \\
\text { 7-9 agar protein tidak } \\
\text { rusak. }\end{array}$ \\
\hline 2. & $\mathrm{NaCl}$ & $0,877 \mathrm{~g}$ & $\begin{array}{l}\text { Mengendapkan } \\
\text { protein. }\end{array}$ \\
\hline 3. & $\begin{array}{l}\text { Nonidet } \\
\text { P-40 }\end{array}$ & $\begin{array}{l}0,125 \\
\mathrm{~mL}\end{array}$ & $\begin{array}{l}\text { Detergen non ionik } \\
\text { untuk melarutkan } \\
\text { protein membran. }\end{array}$ \\
\hline 4. & EDTA & $0,007 \mathrm{~g}$ & $\begin{array}{l}\text { Melindungi protein } \\
\text { dari ion logam. }\end{array}$ \\
\hline 5. & PMSF & $0,009 \mathrm{~g}$ & $\begin{array}{l}\text { Penghambat protease } \\
\text { untuk trypsin, } \\
\text { chymotrypsin, } \\
\text { thrombin, dan papain. }\end{array}$ \\
\hline & $\begin{array}{l}\text { Protease } \\
\text { inhibitor } \\
\text { cocktail }\end{array}$ & $50 \mu 1$ & $\begin{array}{l}\text { Menghambat enzim } \\
\text { protease yang } \\
\text { menyebabkan } \\
\text { denaturasi protein. }\end{array}$ \\
\hline $\begin{array}{l}\text { Pengukuran } \\
\text { Menggunakan ELISA }\end{array}$ & Kadar & GLUT-4 \\
\hline
\end{tabular}

Larutan standar yang berfungsi untuk membentuk kurva baku dibuat dengan berbagai konsentrasi $(96,48,24.12$, 6, 3, $0 \mu \mathrm{g} / \mathrm{L})$. Larutan standar dan sampel dimasukkan ke dalam sumur ELISA, piringan ELISA diinkubasi selama 30 menit pada suhu $37^{\circ} \mathrm{C}$, lalu dicuci selama 30 detik dan diulangi 5 kali dengan $200 \mu \mathrm{l}$ wash solution. Ditambahkan $50 \mu \mathrm{l}$ HRPConjugate reagent, lalu diinkubasi dan dicuci kembali. Ditambahkan masingmasing sebanyak $50 \mu \mathrm{l}$ Chromogen solution $A$ dan $B$, lalu diinkubasi selama 30 menit pada suhu $37^{\circ} \mathrm{C}$ dan ditambahkan stop solution sebanyak $50 \mu 1$. Kemudian, Sampel dibaca absorbansinya yang diatur pada panjang gelombang $450 \mathrm{~nm}$.Konsentrasi GLUT-4 sampel diperoleh dengan memasukkan nilai absorbansi GLUT-4 ke dalam persamaan kurva baku.

\section{Analisa Data}

\section{Isolasi Protein}


Hasilpengukuran konsentrasi GLUT-4 di jaringan otot kelompok kontroldanperlakuandianalisasecarastatisti $\mathrm{k}$ dengan menggunakan uji bedatingkatsignifikansi $0,05 \quad(p=0,05)$ dantarafkepercayaan $95 \% \quad(\alpha=0,05)$ Langkah-langkahujihipotesisbeda adalahsebagaiberikut:uji normalitas data, ujihomogenitasvarian, uji One way ANOVA, dan uji Post hoc.

\section{HASIL PENELITIAN}

Hasil Uji Fitokimia

Tabel 2. Hasil Uji Fitokimia

\begin{tabular}{|c|c|c|c|}
\hline No. & $\begin{array}{c}\text { Jenis Uji } \\
\text { Fitokimia } \\
\end{array}$ & Pereaksi & Hasil \\
\hline 1. & $\begin{array}{l}\text { Uji } \\
\text { minyak } \\
\text { atsiri }\end{array}$ & $\begin{array}{l}\text { Sudan } \\
\text { III }\end{array}$ & $\begin{array}{l}\text { Perubahan } \\
\text { warna } \\
\text { ekstrak } \\
\text { dari hijau } \\
\text { kecoklatan } \\
\text { menjadi } \\
\text { merah tua }\end{array}$ \\
\hline 2. & $\begin{array}{l}\text { Uji } \\
\text { saponin }\end{array}$ & - & $\begin{array}{l}\text { Terdapat } \\
\text { busa di } \\
\text { permukaan } \\
\text { ekstrak } \\
\text { setinggi < } \\
1 \mathrm{~cm} \\
\text { selama } 10 \\
\text { menit }\end{array}$ \\
\hline \multirow[b]{2}{*}{3.} & \multirow[t]{2}{*}{$\begin{array}{l}\text { Uji } \\
\text { alkaloid }\end{array}$} & Mayer & $\begin{array}{l}\text { Terdapat } \\
\text { endapan } \\
\text { berwarna } \\
\text { kuning }\end{array}$ \\
\hline & & Wagner & $\begin{array}{l}\text { Terdapat } \\
\text { endapan } \\
\text { berwarna } \\
\text { merah } \\
\text { kecoklatan }\end{array}$ \\
\hline
\end{tabular}

\section{Hasil Pengukuran Glukosa Darah Puasa}

Pada nilai GDP (mg/dL) dilakukan uji korelasi dengan pakan tinggi kalori yang dikonsumsi hewan coba (kkal). Uji korelasi Pearson menunjukkan nilai signifikansi $0,01(p<0,05)$ dengan koefisien korelasi 0,506 . Sehingga dapat diambil kesimpulan terdapat korelasi yang signifikan antara pakan tinggi kalori yang dikonsumsi hewan coba dan nilai GDP dengan korelasi positif dan kekuatan korelasi sedang.

\section{Gambar 1. Grafik Pengaruh Pakan Tinggi Kalori terhadap Nilai Glukosa Darah Puasa Hewan Coba.}

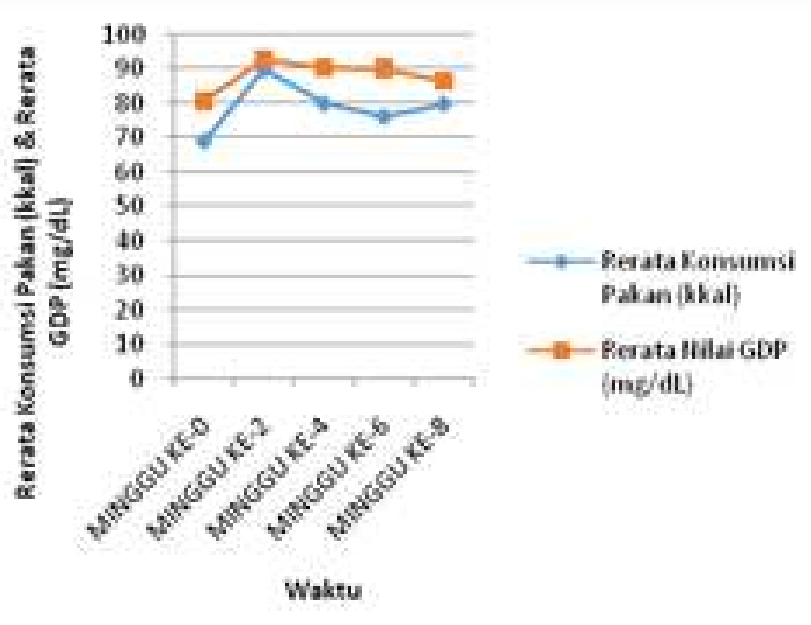

Ekstr? menganuunz minyak

abel 3. Rerata Penurunan Nilai

Glukosa Darah Puasa

\begin{tabular}{|c|c|c|}
\hline $\begin{array}{l}\text { Kelompok } \\
\text { Perlakuan }\end{array}$ & $\mathrm{N}$ & $\begin{array}{l}\text { Rerata Penurunan GDP } \\
(\mathrm{mg} / \mathrm{dL})) \pm \mathrm{SD}\end{array}$ \\
\hline Pn & 2 & $82,50 \pm 126,57$ \\
\hline $\mathrm{P} 1$ & 3 & $298,00 \pm 175,60$ \\
\hline ndung2 & 2 & $107,00 \pm 42,43$ \\
\hline n P3 & 3 & $170,67 \pm 129,31$ \\
\hline $\mathrm{Pp}$ & 2 & $236,50 \pm 68,59$ \\
\hline
\end{tabular}

$\mathrm{P}_{\mathrm{n}}$ : hewan coba model DM Tipe 2 tanpa terapi; $\mathrm{P}_{1}$ : hewan coba model DM tipe $2+$ terapi ekstrak biji jintan hitam 24 $\mathrm{mg} / \mathrm{kgBB} /$ hari; $\mathrm{P}_{2}$ : hewan coba model DM tipe $2+$ terapi ekstrak biji jintan hitam 48 $\mathrm{mg} / \mathrm{kgBB} /$ hari; $\mathrm{P}_{3}$ : hewan coba model DM Eksratipe $2+$ terapi ekstrak biji jintan hitam 96

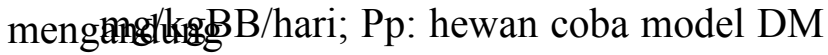
alkaldiqe 2 + terapi metformin $75 \mathrm{mg} / \mathrm{kgBB} /$ hari; tanda minus (-) menunjukkan terjadinya penurunan nilai GDP.

Kelompok perlakuan yang diberi ekstrak biji jintan hitam $24 \mathrm{mg} / \mathrm{kgBB} /$ hari $\left(\mathrm{P}_{1}\right)$ memiliki penurunan GDP paling besar, kemudian diikuti oleh kontrol positif $\left(\mathrm{P}_{\mathrm{p}}\right)$ yang diberi metformin $75 \mathrm{mg} / \mathrm{kgBB} / \mathrm{hari}$, kelompok esktrak biji jintan hitam 96 $\mathrm{mg} / \mathrm{kgBB} /$ hari $\left(\mathrm{P}_{3}\right)$, esktrak biji jintan hitam $48 \mathrm{mg} / \mathrm{kgBB} / \mathrm{hari}\left(\mathrm{P}_{2}\right)$, dan kontrol negatif $\left(\mathrm{P}_{\mathrm{n}}\right)$ yang diberi $10 \%$ tween 80 .

\section{Hasil Pengukuran Berat Badan}




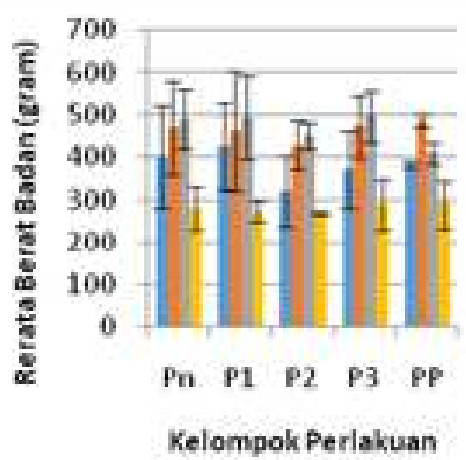

E Rerata Berat Badan Aval (gram)

E Rerata Berat

Eadan

Mingsuke-4 (gram)

Gambar 2. Grafik Rerata Berat Badan Hewan Coba dari Minggu ke-0 hingga Minggu ke-12. Data ditampilkan dalam rerata \pm standar deviasi. Kelompok perlakuan yang mengalami peningkatan $\mathrm{BB}$ terbesar adalah kelompok $\mathrm{P}_{2}$ dengan rerata peningkatan $\mathrm{BB}$ sebanyak 129,15 $\pm 51,41$ gram. Namun, setelah dilakukan injeksi STZ (minggu ke-8) terjadi penurunan BB pada hewan coba bahkan hingga akhir masa terapi, kelompok perlakuan yang mengalami penurunan $\mathrm{BB}$ terbesar adalah kelompok $\mathrm{P}_{1}$ dengan rerata penurunan $\mathrm{BB}$ sebanyak $214,01 \pm 83,57$ gram.

\section{Hasil Pengukuran Konsentrasi GLUT-4 di Jaringan Otot}

Pengukuran konsentrasi GLUT-4 dilakukan menggunakan ELISA kit. Konsentrasi GLUT-4 diperoleh dengan memasukkan nilai absorbansi GLUT-4 ke dalam persamaan kurva baku sebagai berikut:

$$
\begin{array}{ll}
\mathrm{Y} & =0,0101 \mathrm{x}-0,0432 \\
\mathrm{R}^{2} & =0,994
\end{array}
$$

keterangan : $\quad \mathrm{y}=$ absorbansi

$$
\mathrm{x}=\text { konsentrasi }
$$

Tabel 4. Rerata Konsentrasi GLUT-4 Jaringan Otot

\begin{tabular}{cc}
$\begin{array}{c}\text { Kelompok } \\
\text { Perlakuan }\end{array}$ & $\begin{array}{c}\text { Rerata Konsentrasi GLUT-4 } \\
(\boldsymbol{\mu g} / \mathbf{d L})) \pm \text { SD }\end{array}$ \\
\hline Pn & $14,72 \pm 0,88$ \\
P1 & $15,40 \pm 2,42$ \\
P2 & $16,56 \pm 0,77$ \\
P3 & $17,44 \pm 3,97$ \\
Pp & $17,56 \pm 3,38$ \\
\hline
\end{tabular}

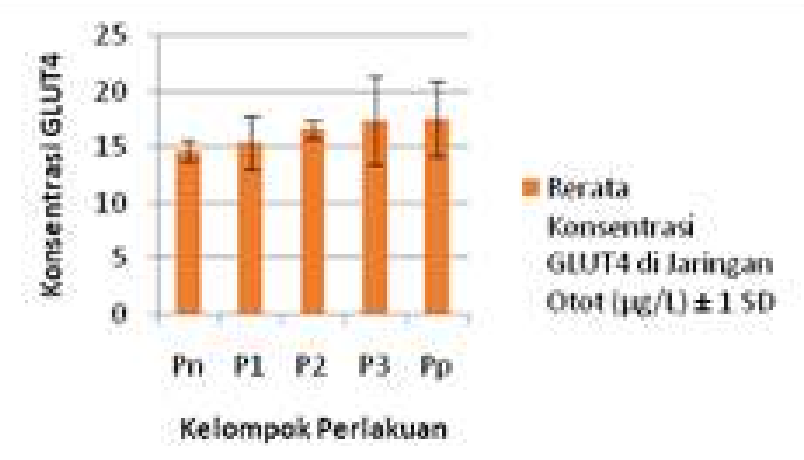

Gambar 3. Gratilk Rerata Konsentrasí GLUT-4 di Jaringan Otot. Data ditampilkan dalam rerata \pm standar deviasi. Konsentrasi GLUT-4 terendah pada kelompok kontrol negatif dan yang tertinggi pada kelompok kontrol positif. tidak terdapat perbedaan konsentrasi GLUT-4 jaringan otot yang signifikan antar kelompok (ANOVA, $p=0,371$ ).

\section{PEMBAHASAN}

\section{Ekstraksi Serbuk Biji Jintan Hitam}

Ekstrak biji jintan hitam yang diperoleh dari proses ekstraksi maserasi adalah ekstrak dengan 2 fase yaitu fase padat dan minyak. Hasil ekstraksi yang diperoleh telah sesuai dengan literatur yang dirujuk yaitu jurnal Andaloussi tahun 2011, dimana dari hasil ekstraksi diperoleh ekstrak dengan 2 fase yaitu fase padat dan minyak dengan komposisi $30 \%$ berupa padatan dan $70 \%$ berupa minyak. Proporsi tersebut berbeda dengan yang diperoleh pada penelitian ini, dari hasil ekstraksi diperoleh fase padat yang lebih banyak dibandingkan fase minyak. Hal ini dapat disebabkan oleh perbandingan jumlah antara serbuk biji jintan hitam dengan pelarut etanol yang berbeda, pada penelitian Andaloussi tahun 2011 tidak disebutkan perbandingan jumlah serbuk dengan pelarut yang digunakan. Peneliti menggunakan perbandingan 1:3 karena merupakan hasil optimasi dari penelitian sebelumnya dan merujuk pada proses ekstraksi serbuk biji jintan hitam dengan pelarut etanol yang dilakukan oleh Laboratorium Penelitian dan Pengujian Terpadu Universitas Gadjah Mada (LPPT UGM).

\section{Uji fitokimia}

Hasil positif pada uji minyak atisiri menunjukkan kemungkinan adanya 
thymoquinone yang terkandung di dalam ekstrak biji jintan hitam yang digunakan untuk terapi hewan coba dengan DM tipe 2, sehingga menghasilkan perbedaan konsentrasi GLUT-4 jaringan otot antar kelompok. Uji alkaloid dilakukan dengan pereaksi Mayer (Potassiomercuric Iodide) dan Wagner (Iodo-potassium iodide). Hasil positif pada uji Mayer ditunjukkan dengan terbentuknya endapan berwarna kuning. Endapan tersebut merupakan kompleks yang terbentuk dari kalium dan alkaloid. Alkaloid mengandung nitrogen yang memiliki pasangan elektron bebas sehingga dapat digunakan untuk membentuk ikatan kovalen koordinat dengan ion logam, nitrogen tersebut akan bereaksi dengan ion logam kalium dari kalium tetraiodomerkurat sehingga akan terbentuk kompleks kalium-alkaloid yang mengendap ${ }^{16}$. Hasil positif terdapat alkaloid dengan menggunakan pereaksi Wagner ditandai dengan terbentuknya endapan berwarna merah kecoklatan. Endapan tersebut adalah kompleks kalium-alkaloid, ion logam kalium akan membentuk ikatan kovalen koordinat dengan nitrogen pada alkaloid sehingga membentuk kompleks yang mengendap ${ }^{16}$.

Pada uji saponin yang dilakukan menunjukkan ekstrak biji jintan hitam positif mengandung saponin. Timbulnya busa pada uji saponin menunjukkan adanya glikosida yang memiliki kemampuan membentuk buih dalam air yang terhidrolisis menjadi glukosa dan senyawa lainnya ${ }^{16}$.

\section{Efek Pemberian Pakan Tinggi Kalori dan Injeksi STZ terhadap Kadar Glukosa Darah Puasa}

Induksi pakan tinggi kalori selama dua bulan mengakibatkan peningkatan $\mathrm{BB}$ dan nilai GDP. Peningkatan BB terjadi karena konsumsi pakan yang kaya akan energi yaitu dalam bentuk lemak jenuh (lemak babi) dan lemak tersebut terdeposisi di berbagai bantalan lemak tubuh.

Konsumsi pakan tinggi kalori mengakibatkan peningkatan kadar trigliserida (TG) karena asupan lemak yang berlebihan, hal ini merupakan sumber peningkatan ketersediaan asam lemak ${ }^{21}$. Peningkatan ketersediaan asam lemak di sirkulasi akan menurunkan proses glikolisis akibatnya terjadi peningkatan konsentrasi glukosa intraseluler dan penurunan ambilan glukosa oleh $\operatorname{otot}^{7}$. Oleh karena itu, pemberian pakan tinggi kalori dapat meningkatan kadar GDP hewan coba namun tidak semua hewan coba mengalami hiperglikemia ringan yaitu dengan kadar glukosa darah 117-144 mg/dL ${ }^{11}$. Hal tersebut terjadi karena durasi pemberian konsumsi pakan tinggi kalori kurang lama sehingga pemberian pakan selama dua bulan masih belum cukup untuk mengakibatkan hiperglikemia ringan.

Berdasarkan penelitian Wang (2007), pemberian pakan tinggi kalori selama satu bulan belum mengakibatkan hiperglikemia ringan, namun telah terjadi perubahan ekspresi gen yang mengarah pada kondisi resistensi insulin seperti penurunan kadar mRNA ADIPOR1 dan ADIPOR2 pada liver. ADIPOR1 dan ADIPOR2 merupakan reseptor untuk adiponektin, penurunan kadar atau gangguan fungsi pada ADIPOR1 dan ADIPOR2 mengakibatkan terjadinya resistensi insulin di jaringan perifer ${ }^{25}$.

Kemudian induksi DM tipe 2 dilanjutkan dengan injeksi STZ 30 $\mathrm{mg} / \mathrm{kgBB}$ yang mengakibatkan penurunan berat badan pada hewan coba, hal ini dikarenakan proses proteolisis yaitu pemecahan protein menjadi asam amino karena tubuh tidak mampu mengambil glukosa sebagai sumber energi, selain itu penurunan berat badan terjadi karena proses lipolisis dan glikogenolisis ${ }^{3}$. STZ memiliki struktur yang mirip dengan glukosa, STZ masuk ke dalam sel $\beta$ pankreas melalui transporter GLUT-2 yang mengakibatkan kerusakan DNA dan mengakibatkan kematian sel, sehingga kehilangan fungsinya untuk menghasilkan insulin ${ }^{24}$. Setelah dilakukan Injeksi STZ diperoleh nilai GDP $\geq 200 \mathrm{mg} / \mathrm{dL}$ pada seluruh hewan coba, sehingga seluruh hewan coba telah mengalami DM tipe 2. 


\section{Efek Pemberian Ekstrak Biji Jintan Hitam terhadap Perbedaan Konsentrasi GLUT-4 di Jaringan Otot}

Hasil absorbansi sampel yang diperoleh dibawah rentang normal yaitu 0,2-0,8 sehingga konsentrasi GLUT-4 jaringan otot yang diperoleh kecil pula. Namun, konsentrasi yang diperoleh berada dalam rentang deteksi ELISA yaitu $2 \mu \mathrm{g} / \mathrm{L}-$ $48 \mu \mathrm{g} / \mathrm{L}$.

Injeksi STZ menginduksi penurunan ekspresi mRNA GLUT-4 ${ }^{19}$. Hal ini mengakibatkan ambilan glukosa ke dalam jaringan otot menurun sehingga terjadi peningkatan kadar glukosa dalam darah. Kelompok hewan coba yang diberi terapi metformin memiliki konsentrasi GLUT-4 di jaringan otot paling besar diantara kelompok lainnya (gambar 3). Metformin merupakan obat yang efektif untuk menurunkan kadar glukosa darah dengan cara menurunkan produksi glukosa hepatik dan meningkatkan penyimpanan glukosa di otot polos dengan cara meningkatkan aktivitas $\mathrm{AMPK}^{17}$. Peningkatan aktivitas AMPK tersebut dapat mengakibatkan terjadinya peningkatan sintesis dan translokasi GLUT-4 di jaringan otot. Namun tidak ada perbedaan konsentrasi GLUT-4 yang signifikan antara kelompok kontrol postif dengan kelompok lainnya, hal ini dapat terjadi karena durasi terapi yang kurang lama, karena berdasarkan jurnal Musi tahun 2002, metformin dapat menginduksi peningkatan aktivitas AMPK di jaringan otot secara signifikan dengan lama terapi 10 minggu $^{17}$.

Nilai rerata konsentrasi GLUT-4 pada kelompok tikus yang diberi ekstrak biji jintan hitam, baik dengan dosis 24,48 , atau $96 \mathrm{mg} / \mathrm{kgBB} /$ hariberada diatas kelompok kontrol negatif, namun tidak signifikan. Hal ini menunjukkan bahwa ekstrak biji jintan hitam dapat meningkatkan sintesis GLUT-4 pada jaringan otot. Hasil tersebut sesuai dengan jurnal Andaloussi tahun 2011, dimana dengan pemberian ekstrak biji jintan hitam selama satu bulan dapat meningkatkan konsentrasi total GLUT-4 di jaringan otot tikus. Komponen utama ekstrak biji jintan hitam yang berperan dalam sintesis GLUT-
4 di jaringan otot adalah thymoquinone yang termasuk dalam golongan minyak atsiri, dimana zat tersebut berfungsi sebagai antiinflamasi. Thymoquinone tidak bekerja langsung pada aktivitas AMPK yang berperan dalam sintesis dan translokasi GLUT-4 sehingga konsentrasi total GLUT4 di jaringan otot yang diperoleh setelah dilakukan terapi selama satu bulan dengan ekstrak biji jintan hitam tidak berbeda signifikan dengan kelompok perlakuan lainnya.

\section{Efek Pemberian Ekstrak Biji Jintan Hitam terhadap Perbedaan Kadar Glukosa Darah Puasa}

Ekstrak biji jintan hitam dapat menurunkan kadar GDP (tabel 3), pemberian dosis ekstrak biji jintan hitam 24 $\mathrm{mg} / \mathrm{kgBB} /$ hari memberikan penurunan GDP yang paling besar. Pada jurnal Alimohammadi tahun 2013 tentang efek ekstrak biji jintan hitam terhadap konsentrasi glukosa darah, terdapat beberapa mekanisme jintan hitam dalam memperbaiki glukosa darah diantaranya adalah peningkatan sensitivitas insulin, penurunan stress oksidatif sehingga dapat menjaga sel $\beta$ pankreas yang mengakibatkan peningkatan kadar insulin, selain itu dapat meregenerasi sebagian selsel islet yang disebabkan oleh injeksi STZ. STZ menginduksi terjadinya degenerasi pankreas dengan menurunkan ukuran dan jumah islet Langerhans, karena kemampuan jintan hitam dalam menjaga dan meregenerasi sel islet tersebut sehingga dapat menurunkan GDP lebih besar dibandingkan kelompok kontrol yang diberi metformin.

Metformin tidak dapat mengakibatkan pelepasan insulin dari pankreas, cara kerja metformin dalam menurunkan kadar glukosa darah adalah dengan meningkatkan ambilan glukosa perifer, menurunkan pelepasan glukosa hepatik, dan mengganggu absorbsi glukosa di usus ${ }^{6}$. Penurunan GDP paling besar terjadi pada kelompok $\mathrm{P}_{1}$ hal ini dikarenakan semakin besar dosis thymoquinone yang diberikan, maka akan terjadi penurunan glutathione (GSH) yang 
merupakan antioksidan utama yang dapat mengikat radikal bebas. Berdasarkan jurnal Mansour tahun 2001, thymoquinone sebanyak $2 \mathrm{~g} / \mathrm{kg}$ BB dan $3 \mathrm{~g} / \mathrm{kg}$ BB yang diberikan secara oral dapat mengakibatkan penurunan $\mathrm{GSH}^{15}$.

Pada penelitian ini dosis terbesar yang diberikan adalah $96 \mathrm{mg} / \mathrm{kgBB} / \mathrm{hari}$ ekstrak biji jintan hitam, sehingga jauh dari dosis yang dapat menurunkan kadar GSH. Oleh karena itu, ketidaksesuaian ini dapat dikarenakan oleh berbagai faktor, yaitu:

1. Tingkat stress yang dialami masingmasing hewan coba berbeda-beda, dimana stress dapat meningkatkan kadar glukosa darah.

2. Perbedaan aktivitas dari masingmasing hewan coba. Semakin tinggi aktivitas maka dapat menurunkan kadar glukosa darah lebih banyak.

3. Perbedaan genetik yang mempengaruhi respon tikus, akibatnya terdapat variasi nilai GDP meskipun berada dalam satu kelompok perlakuan yang sama.

Pada kelompok $\mathrm{P}_{\mathrm{n}}$ terdapat dua tikus yang masih hidup hingga akhir perlakuan, satu tikus mengalami peningkatan GDP sedangkan tikus lainnya mengalami penurunan GDP. Berdasarkan studi pustaka tidak ditemukan adanya efek $10 \%$ tween 80 dalam menurunkan kadar glukosa darah, satu tikus mengalami penurunan kadar GDP meskipun tidak diberi terapi kemungkinan karena respon kompensasi dari tubuh hewan coba tersebut untuk menurunkan kadar glukosa darah misalnya dengan meningkatkan sekresi insulin, meningkatkan penyimpanan glukosa baik pada otot maupun liver, atau karena aktivitas yang berbeda dengan tikus lainnya.

\section{KESIMPULAN}

1. Terdapat perbedaan konsentrasi GLUT-4, namun tidak signifikan secara statistik, di jaringan otot tikus putihstrain Wistarmodel DM tipe 2 yang mendapatkan terapi ekstrak biji jintan hitam, metformin, dan tanpa terapi.
2. Pada kelompok terapi ekstrak biji jintan hitam, kelompok yang memiliki rerata konsentrasi GLUT-4 di jaringan otot tertinggi adalah tikus putihstrain Wistarmodel DM tipe 2 yang mendapatkan terapi ekstrak biji jintan hitam $96 \mathrm{mg} / \mathrm{kg}$ BB meskipun tidak berbeda signifikan secara statistik dengan kelompok dosis lainnya.

\section{SARAN}

Dibutuhkan penelitian lebih lanjut mengenai prosedur induksi DM tipe 2 yang meliputi pemberian pakan tinggi kalori yang mengakibatkan resistensi insulin dan injeksi STZ sehingga dihasilkan nilai GDP $\geq 200 \mathrm{mg} / \mathrm{dL}$ dengan tingkat kematian yang rendah pada usia tikus 12 bulan. Selain itu, perlu dilakukan pengukuran thymoquinone secara kuantitatif, sehingga dapat mengetahui kadar thymoquinone yang mengakibatkan adynamic ileus.

\section{DAFTAR PUSTAKA}

Abukhader MM. The Effect of Route of Administration in Thymoquinone Toxicity in Male and Female Rats. Indian J Pharm Sci, 2012; 74 (3): 195-200.

Alimohammadi S, Rahim H, Javad J, Danial K, Reza M, Maryam T, Farshid K, and Hamid A. Protective and antidiabetic effects of extract from Nigella sativa on blood glucose concentrations against streptozotocin (STZ)induced diabetic in rats: an experimental study with histopathological evaluation. Diagnostic pathology, 2013; 8(1): 137.

Almeida DATD, Camila PB, Ethel LBN, and Ana AHF. Evaluation of Lipid Profile and Oxidative Stress in STZ- Induced Rats Treated with Antioxidant Vitamin. Braz. Arch. Biol. Technol, 2012; 55 (4): $527-$ 536.

American Diabetes Association (ADA), 2013. Diabetes Basics, (Online), (http://www.diabetes.org/diabetes 
-basics/type-2/?loc $=$ db-slabnavi, diakses 21 November 2013).

Andaloussi AB, Louis M, Tri V, Bouchra M, Padma M, Abdellatif S, and Pierre SH. The In Vivo Antidiabetic Activity of Nigella sativa Is Mediated through Activation of the AMPK Pathway and Increased Muscle GLUT4 Content. eCAM, 2011; 2011: 1-9.

Bastaki, S. Review Diabetes Mellitus and Its Treatment. Int $J$ Diabetes \& Metabolism, 2005; 13: 111 -134.

Cahová MH, Vavrínková, and Kazdová. Glucose-fatty acid interaction in skeletal muscle and adipose tissue in insulin resistance. Physiol res, 2007; 56 (1): 1-15.

Cook, Christopher L., John T. Johnson, and William E. Wade. 2008. Pharmacotherapy: Principles and Practice, Edited by Marie AC, Barbara GW, Terry, LS, Patrick MM, Jill MK, John CR, Joseph TD, The McGraw-Hill Companies, Inc., USA, p. 643666.

Debas HT. 2004. Gastrointestinal Surgery: Pathophysiology and Management. Springer-Verlag New York, Inc., USA, p. 250.

Departemen Kesehatan Republik Indonesia. 1989. Materia Medika Indonesia, Jilid V. Menteri Kesehatan. Jakarta.

Gauguier D, Bihoreau MT, Picon L, and Ktorza A. Insulin secretion in adult rats after intrauterine exposure to mild hyperglycemia during late gestation. Diabetes, 1991, 40 (2): 109-114.

Gilani AH, Khan MAU. A Review of Medicinal Uses and Pharmacological Activities of Nigella sativa. Pak. J. Biol. Sci, 2004; 7 (4): 441-451.

Harzallah HJ, Rahma G, Wafa K, Aya M, Mohamed $\mathrm{H}$ and Touhami $\mathrm{M}$. Thymoquinone, the Nigella sativa bioactive compound, prevents circulatory oxidative stress caused by 1,2-dimethylhydrazine in erythrocyte during colon postinitiation carcinogenesis. Oxid Med Cell Longev, 2012; 2012: 16.

Kola B, Ashley BG, and Márta K. The Role of AMP-Activated Protein Kinase in Obesity. Front Horm Res, 2008; 36: 198-211.

Mansour MA, OT Ginawi, T El-Hadiyah, AS El-Khatib, and OA AlShabanah, HA Al-Sawaf. Effect of Volatile Oil Constituents of Nigella Sativa on Carbon Tetrachloride-Induced Hepatotoxicity in Mice: Evidence for Antioxidant Effects of Thymoquinone. Res. Commun. Mol. Pathol. Pharmacol, 2001; 110 (3\&4): 239-251.

Marliana SD, Venty S, and Suyono. Screening Fitokimia dan Analisis Kromatografi Lapis Tipis Komponen Kimia Buah Labu Siam (Sechium edule Jacq . Swartz.) dalam Ekstrak Etanol. Biofarmasi, 2005; 3 (1): 26-31.

Musi N, Michael FH, Jonas N, Monika S, Peter B, Olav R, Gaochao Z, Joanne MW, Olle L, Suad E, David EM, Anders T, and Laurie J Goodyear. Metformin Increases AMP-Activated Protein Kinase Activity in Skeletal Muscle of Subjects With Type 2 Diabetes. Diabetes, 2002; 51: 2074-2081.

Nikzamir A, Alireza P, Alireza K, and Hashemi T. Expression of Glucose Transporter 4 (GLUT4) is Increased by Cinnamaldehyde in C2C12 Mouse Muscle Cells. Iran Red Crescent Med J, 2014; 16 (2): $10-14$

Olson AL. Regulation of GLUT4 and Insulin-Dependent Glucose Flux. Molecular Biology, 2012; 2012.

Rehman AU, Muhammad AS, Suhel A. Effect of Exercise and Muscle Contraction on Insulin Action, Transportation and Sensitivity and Muscle Fibres in type II Diabetes Mellitus. Am J Med Sci, 2012; 2(6): 131-135. 
Srinivasan K, B Viswanad, Lydia A, CL Kaul, and $\mathrm{P}$ Ramarao. Combination of high-fat diet-fed and low-dose streptozotocintreated rat: a model for type 2 diabetes and pharmacological screening. Pharmacological research: the official journal of the Italian Pharmacological Society, 2005; 52 (4):313-20.

Steinberg GR, Belinda JM, Bryce JWVD, Matthew JW, Andrew LC, Barbara CF, Sofianos A, Joseph P, Cem ZG, David C, Gökhan SH, Mark AF, Thomas WK, and Bruce EK. Tumor necrosis factora-induced skeletal muscle insulin resistance involves suppression of AMPkinase signaling. Cell Metabolism, 2006; 4, 465-474.

Thévenod F. Pathophysiology of Diabetes Mellitus Type 2: Roles of Obesity, Insulin Resistance and $\beta$-Cell Dysfunction. Diabetes and Cancer. Epidemiological Evidence and Molecular Links, 2008; 19: 1-18.

Ventura-Sobrevilla J, VD Boone-Villa, CN Aguilar, R Román-Ramos, E Vega-Avila, E CamposSepúlveda, and F Alarcón-Aguilar. Effect of Proceedings of the Western Pharmacology Societydose and Administration of Streptozotocin on Blood Sugar in Male CD1 Mice. Proc. West. Pharmacol. Soc., 2011; 54: 5-9.

Wang HJ, Yuan XJ, Wan S, Jing N, Tao W, Yong JL, and Zheng WF. Low dose streptozocin (STZ) combined with high energy intake can effectively induce type 2 diabetes through altering the related gene expression. Asia Pac J Clin Nutr, 2007; 16 (1): 412-417. 